\title{
Gel mobility shift scanning of pectin-inducible promoter from Penicillium griseoroseum reveals the involvement of a CCAAT element in the expression of a polygalacturonase gene
}

\author{
Andréa de O.B. Ribon ${ }^{1}$, João Batista Ribeiro², Daniel B. Gonçalves ${ }^{3}$, Marisa V. de Queiroz ${ }^{3}$ \\ and Elza F. de Araújo ${ }^{3}$ \\ ${ }^{I}$ Departamento de Bioquímica e Biologia Molecular, Universidade Federal de Viçosa, Viçosa, MG, Brazil. \\ ${ }^{2}$ EMBRAPA Suínos e Aves, Concórdia, SC, Brazil. \\ ${ }^{3}$ Departamento de Microbiologia, Universidade Federal de Viçosa, Viçosa, MG, Brazil.
}

\begin{abstract}
Previous reports have described pgg2, a polygalacturonase-encoding gene of Penicillium griseoroseum, as an attractive model for transcriptional regulation studies, due to its high expression throughout several in vitro growth conditions, even in the presence of non-inducing sugars such as sucrose. A search for regulatory motifs in the 5' upstream regulatory sequence of $p g g 2$ identified a putative CCAAT box that could justify this expression profile. This element, located 270 bp upstream of the translational start codon, was tested as binding target for regulatory proteins. Analysis of a $170 \mathrm{bp}$ promoter fragment by electrophoretic mobility shift assay (EMSA) with nuclear extracts prepared from mycelia grown in pectin-containing culture medium revealed a high mobility complex that was subsequently confirmed by analyzing it with a double-stranded oligonucleotide spanning the CCAAT motif. A substitution in the core sequence for GTAGG partially abolished the formation of specific complexes, showing the involvement of the CCAAT box in the regulation of the polygalacturonase gene studied.
\end{abstract}

Key words: Penicillium griseoroseum, polygalacturonase, 5' upstream regulatory sequence, electrophoretic mobility shift assay.

Received: February 7, 2008; Accepted: July 25, 2008.

Polygalacturonases (PGs) are enzymes directed toward the degradation of D-galacturonic acid moieties of pectic substances. Several PG genes have been isolated from filamentous fungi, due to their importance in hostpathogen cross-talks and their industrial relevance, for example, in food and textile processing (Ribon et al., 1999; Wubben et al., 1999; Lang and Dörnenburg 2000; Jayani et al., 2005). These genes are encoded by a multigene family and exhibit a high degree of polymorphism, resulting in enzymes with different biochemical properties, probably a reflection of fungus lifestyle in nature. The PG enzyme is characterized by the presence of eight amino acid residues that are strictly conserved among all groups of organisms and have been implicated in substrate binding and/or catalysis (van Santen et al., 1999).

Fungal PGs are differentially regulated in response to carbon sources. Pectic components are the main inducers of PG genes, but expression is also observed in the presence of simple sugars and other sources, such as corn (Panda et al., 2004). Glucose repression is observed in the majority of the

Send correspondence to Andréa de O.B. Ribon. Departamento de Bioquímica e Biologia Molecular, Universidade Federal de Viçosa, Av. P.H. Rolfs, s/n, Campus Universitário, 36570-000 Viçosa, MG, Brazil. E-mail: abribon@ufv.br. genes studied so far, but there are reports of PG genes expressed constitutively regardless of the carbon source (Wubben et al., 2000; Cotton et al., 2003). In the phytopathogenic fungus Botrytis cinerea, the six PG genes characterized so far show different expression patterns, depending on the time and infected tissue (ten Have et al., 2001). In addition, some recent reports confirmed that $\mathrm{pH}$ also triggers PG expression (Wubben et al., 2000; Cotton et al., 2003).

Despite the suggestion that pectic genes are subject to a general pectinolytic regulatory system, studies on the mechanisms involved in the transcriptional regulation of PG genes are scarce (de Vries et al., 2002). Putative ciselements have been described for all isolated PG genes, but there are only few data confirming their participation in gene expression. Among the sequences described, there are indications that CCAAT, SYGGRG or CCCTGA might play an important role in the transcription of PG genes, but no trans-acting factors that regulate genes coding for enzymes of the pectic system have been identified to date (Benen et al., 1996; Ishida et al., 1997; Parenicová et al., 1998).

Previous reports have described pgg2 (GenBank AF195113), a polygalacturonase-encoding gene of 
Penicillium griseoroseum, as an attractive model for transcriptional regulation studies, due to its high expression throughout several different growth conditions, even in the presence of non-inducing sugars such as sucrose, as opposed to $p g g 1$, expressed only in pectin-containing medium, after $76 \mathrm{~h}$ of growth (Ribon et al., 2002). pgg2 is subject to catabolite repression by glucose. Nevertheless, pgg2 transcripts are observed during mycelium cultivation in medium containing glucose and yeast extract, showing that these substances relieve the repression somehow. Since CCAAT has always been referred to as a binding motif for proteins that modulate expression of eukaryotic genes, it was assumed that this element could be important for the constant high-level gene expression observed in the previous work (Ribon et al., 2002). Visual inspection of the 5' upstream gene region for cis motifs likely to represent binding sites for proteins that could explain the expression pattern seen revealed a CCAAT motif located at $-270 \mathrm{bp}$ to the translation start codon whose relevance for pgg2 expression was studied in this work.

Nuclear extracts were prepared from $P$. griseoroseum (CCT 6421) mycelia grown for $24 \mathrm{~h}$ on minimal medium containing pectin as sole carbon source (Nagata et al., 1993; Ribon et al., 2002) and submitted to electrophoretic mobility shift assays (EMSA). As probe, a $170 \mathrm{bp}$ fragment containing the putative CCAAT box was used. It was originated by enzyme cleavage of a $335 \mathrm{bp}$ fragment amplified from plasmid pPG4.3 (pgg2 gene clone) with forward primer 5' TGAGGAATGAATGAATGAATG 3' and reverse primer 5' GGCCATTCTAGACTAGGTGG 3'. The restriction generated products of $85 \mathrm{bp}, 80 \mathrm{bp}$ and $170 \mathrm{bp}$.
The $170 \mathrm{bp}$ fragment was purified from the agarose gel, using the Wizard SV Gel and PCR Clean-Up System (Promega, USA), and radiolabeled with $\left[\gamma_{-}{ }^{32} \mathrm{P}\right] \mathrm{dATP}$ (Sambrook and Russell, 2001). Labeled probes (5 ng) were incubated with nuclear extract at room temperature for $10 \mathrm{~min}$ in a total reaction volume of $20 \mu \mathrm{L}$ containing $4 \mu \mathrm{L}$ of $5 \mathrm{X}$ ligation buffer $(200 \mathrm{mM} \mathrm{KCl}, 5 \mathrm{mM}$ EDTA, $125 \mathrm{mM}$ HEPES-KOH, $\mathrm{pH} 7.0$, and $50 \% \mathrm{w} / \mathrm{v}$ glycerol). For nonspecific competition assays, poly (dI-dC) was added to the reaction. Samples were analyzed by electrophoresis on a $4 \%$ non-denaturating polyacrylamide gel (acrylamide/bisacrylamide 19:1) at $100 \mathrm{~V}$ for $5 \mathrm{~h}$, and then the gel was transferred onto Whatman 3 MM paper, covered with plastic film and exposed to BIOMAX MR film (Kodak) at $-80^{\circ} \mathrm{C}$. Binding assays were also performed with synthetic oligonucleotides spanning the CCAAT motif (5'-TGATTT TCCAATGAGGGGTCC-3' and 5'-GGACCCCTCATTG GAAAATCA-3') and oligonucleotides altered at this site (5'-GATTTTCGTAGGAGGGGTCT-3' and 5'-AGACCC CTCCTACGAAAATC-3'). After annealing, the strands were labeled with $\left[\gamma_{-}{ }^{32} \mathrm{P}\right] \mathrm{dATP}$ using polynucleotide kinase (Promega). For competition assays, a 25- or 50-fold molar excess of the unlabeled oligonucleotide was added to the binding reaction.

When the 170 bp DNA fragment was used as probe, a band shift was observed, independently of the extract concentration employed in the binding reactions, which provides evidence that proteins in the extract recognized the CCAAT element, since it was the most probable ciselement present in the $170 \mathrm{bp}$ fragment (Figure 1A). The experiment was also conducted with nuclear extracts pre-

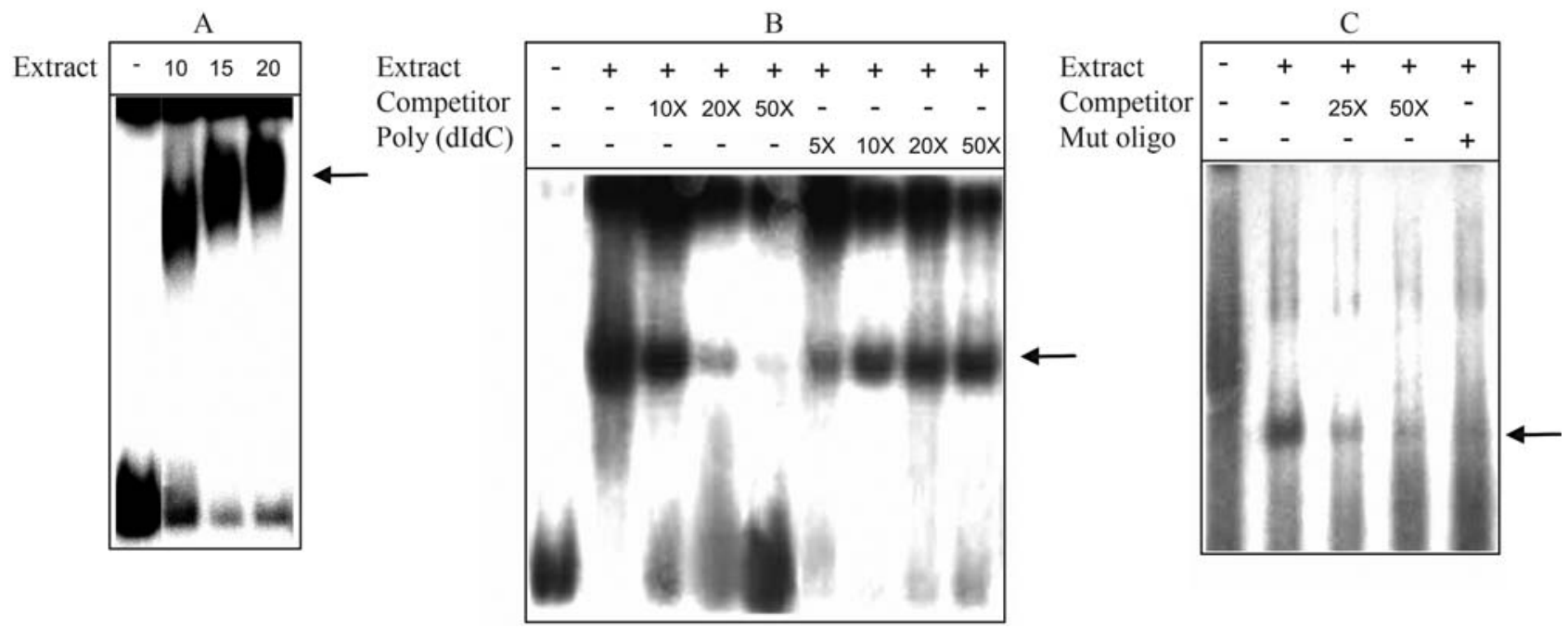

Figure 1 - Electrophoretic mobility shift assays performed with nuclear extracts from Penicillium griseoroseum mycelia cultivated in media containing pectin as sole carbon source. The arrow indicates DNA-protein complexes. (A) A 170 bp DNA fragment containing the CCAAT motif (5 ng) was radiolabeled and used as probe in binding reactions with 10,15 and $20 \mu \mathrm{g}$ of nuclear proteins. (B) The same fragment was incubated with $10 \mu \mathrm{g}$ of nuclear extract prepared from pectin-grown mycelia originated from a different inoculum. Specific competitor was added to the binding reaction at a 10-, 20- and 50 -fold molar excess. Increasing molar excess of poly $(\mathrm{dI}-\mathrm{dC})$ was added as non-specific competitor. (C) Binding reaction mixture containing $10 \mu \mathrm{g}$ of nuclear extracts and a 23 bp radiolabeled oligonucleotide harboring the CCAAT motif or a labeled oligonucleotide (Mut oligo) bearing point mutations in the CAAT element. In competition experiments, a 25- or 50-fold molar excess of unlabeled oligonucleotide was added to the binding reaction. 
pared from mycelia grown in the same way described above, but originated from a different inoculum. Competition assays were performed with increasing concentrations of the non-labeled fragment, which explains the weaker band shifts observed (Figure 1B). However, an excess of the nonspecific competitor poly (dI-dC) did not eliminate band shift. When the electrophoretic mobility shift assay was repeated using the $23 \mathrm{bp}$ double-stranded oligonucleotide as probe, gel retardation activity was again observed. Almost all specific protein-DNA complex formation was abolished upon the substitution of this fragment for a mutant-type oligonucleotide (Figure 1C).

Taken together, these results show that in the polygalacturonase gene studied the sequence CCAAT is responsible for the binding of protein complexes from induced $P$. griseoroseum mycelia that may be important for the expression in vivo. Since pectin and sucrose activate pgg2 gene transcription in the initial $24 \mathrm{~h}$ of in vitro growth, it is reasonable to postulate that the CCAAT sequence may be involved in PG gene expression in other carbon sources as well. Sucrose is not a normal constituent of the pectin molecule, so gene activation may follow a different regulatory pathway not exclusive to the pectinolytic system, but possibly a general one controlled by a CCAAT element. We believe that this element regulates pgg2 expression in pectin as well, but is not involved in the expression of the pggl gene that is induced solely by pectin in $76 \mathrm{~h}$ of fungus growth (Ribon et al., 2002). This hypothesis is consistent with the inexistence of a CCAAT sequence in the pggl promoter (results not shown). CCAAT boxes have been implicated in the modulation of transcript levels in eukaryotes, and their functionality has also been reported for some genes that code for other cell wall degrading enzymes, such as cellulase and xylanase, and enzymes of biotechnological importance like amylase and penicillin (Raymondjean et al., 1988; Litzka et al., 1996; Zeilinger et al., 1996; Zeilinger et al., 1998; Tanaka et al., 2000). Proteins binding to these sequences have been identified in Aspergillus nidulans and Neurospora crassa and resemble the Hap complex of Saccharomyces cerevisiae (Litzka et al., 1996; Chen et al., 1998; Steidl et al., 1999; de Vries et al., 2002). As far as we know, homologues have not yet been described in Penicillium.

Further studies are needed to determine the relationship between the binding of transcriptional regulators in vivo and gene expression level. Since the polygalacturonases are the most extensively studied enzymes in the pectinase family, we believe that new insights into the detailed mechanisms of expression of other polygalacturonase genes will be reported in the near future.

\section{Acknowledgments}

We are grateful to Dr. Gonçalo Apolinário de Souza Filho, who guided us through the firsts gel shift assays, and to Conselho Nacional de Desenvolvimento Científico e
Tecnológico (CNPq) and Fundação de Amparo à Pesquisa do Estado de Minas Gerais (FAPEMIG) for the financial support.

\section{References}

Benen J, Parenicová L, Someren M K-v, Kester H and Visser J (1996) Molecular genetic and biochemical aspects of pectin degradation in Aspergillus. In: Visser $\mathrm{J}$ and Voragen AGJ (eds) Pectins and Pectinases. Elsevier Science, Amsterdam, v. 14, pp 331-346.

Chen H, Crabb JW and Kinsey JA (1998) The Neurospora aab-1 gene encodes a CCAAT binding protein homologous to yeast HAP5. Genetics 148:123-130.

Cotton P, Kasza Z, Bruel C, Rascle C and Fèvre M (2003) Ambient $\mathrm{pH}$ controls the expression of endopolygalacturonase genes in the necrotrophic fungus Sclerotinia sclerotiorum. FEMS Microbiol Lett 227:163-169.

de Vries RP and Visser J (2001) Aspergillus enzymes involved in degradation of plant cell wall polysaccharides. Microb Mol Biol Rev 65:497-522.

de Vries RP, Jansen J, Aguilar G, Parenicová L, Joosten V, Wülfert F, Benen JAE and Visser J (2002) Expression profiling of pectinolytic genes from Aspergillus niger. FEBS Lett 530:41-47.

Ishida Y, Kakibuchi K, Hirao Y and Izumori K (1997) Cloning and characterization of a polygalacturonase-encoding gene from Penicillium janthinellum. J Ferment Bioeng 84:257260.

Jayani RS, Saxena S and Gupta R (2005) Microbial pectinolytic enzymes: A review. Process Biochem 40:2931-2944.

Lang C and Dörnenburg H (2000) Perspectives in the biological function and the technological application of polygalacturonases. Appl Microbiol Biotechnol 53:366-375.

Litzka O, Then Berg K and Brakhage AA (1996) The Aspergillus nidulans penicillin-biosynthsesis gene aat (penDE) is controlled by a CCAAT-containing DNA element. Eur J Biochem 238:675-682.

Nagata O, Takashima T, Tanaka M and Tsukagoshi N (1993) Aspergillus nuclear proteins bind to a CCAAT element and the adjacent upstream sequence in the promoter region of the starch-inducible Taka-amylase A gene. Mol Gen Genet 237:251-260.

Panda T, Sushma R, Nair SR and Kumar MP (2004) Regulation of synthesis of the pectolytic enzymes of Aspergillus niger. Enzyme Microb Technol 34:466-473.

Parenicová L, Benen JAE, Kester HCM and Visser J (1998) pgaE encodes a fourth member of the endopolygalacturonase gene family from Aspergillus niger. Eur J Biochem 251:72-80.

Raymondjean M, Cereghini S and Yaniv M (1988) Several distinct "CCAAT" box binding proteins coexist in eukaryotic cells. Proc Natl Acad Sci USA 85:757-761.

Ribon AOB, Coelho JLC, Barros EG and Araújo EF (1999) Cloning and characterization of a gene encoding the endopolygalacturonase of Penicillium griseoroseum. Biotechnol Lett 21:365-399.

Ribon AOB, Queiroz MV, Coelho JLC and Araújo EF (2002) Differential expression of polygalacturonase-encoding genes from Penicillium griseoroseum in different carbon sources. J Ind Microbiol Biotechnol 29:145-148. 
Sambrook J and Russell, DW (2001) Molecular Cloning: A Laboratory Manual. 3rd edition. Cold Spring Harbor Laboratory Press, Cold Spring Harbor.

Steidl S, Papagiannopoulos P, Litzka O, Andrianopoulos A, Davis MA, Brakhage AA and Hynes MJ (1999) AnCF, the CCAAT binding complex of Aspergillus nidulans, contains products of the $h a p B$, hapC, and hapE genes and is required for activation by the pathway-specific regulatory gene amdR. Mol Cell Biol 19:99-106.

Tanaka A, Kato M, Hashimoto H, Kamei KI, Naruse F, Papagiannopoulos P, Davis MA, Hynes MJ, Kobayashi T and Tsukagoshi N (2000) An Aspergillus oryzae CCAATbinding protein, AoCP, is involved in the high-level expression of the Taka-amylase A gene. Curr Genet 37:380387.

ten Have A, Breuil WO, Wubben JP, Visser J and van Kan JAL (2001) Botrytis cinerea endopolygalacturonase genes are differentially expressed in various plant tissues. Fung Genet Biol 33:97-105.

van Santen Y, Benen JAE, Schröter KH, Kalk KH, Armand S, Visser J and Dijkstra BW (1999) 1.68- $\AA$ crystal structure of endopolygalacturonase II from Aspergillus niger and identi- fication of active site residues by site-directed mutagenesis. J Biol Chem 274:30474-30480.

Wubben JP, Mulder W, ten Have A, van Kan JAL and Visser J (1999) Cloning and partial characterization of endopolygalacturonase genes from Botrytis cinerea. Appl Environ Microbiol 65:1596-1602.

Wubben JP, ten Have A, van Kan JAL and Visser J (2000) Regulation of endopolygalacturonase gene expression in Botrytis cinerea by galacturonic acid, ambient $\mathrm{pH}$ and carbon catabolite repression. Curr Genet 37:152-157.

Zeilinger S, Mach RL, Schindler M, Herzog P and Kubicek CP (1996) Different inducibility of expression of the two xylanase genes xyn 1 and xyn 2 in Trichoderma reesei. J Biol Chem 271:25624-25629.

Zeilinger S, Mach RL and Kubicek CP (1998) Two adjacent protein binding motifs in the cbh2 (cellobiohydrolase II-encoding) promoter of the fungus Hypocrea jecorina (Trichoderma reesei) cooperate in the induction by cellulose. J Biol Chem 51:34463-34471.

Associate Editor: Sérgio Olavo Pinto da Costa

License information: This is an open-access article distributed under the terms of the Creative Commons Attribution License, which permits unrestricted use, distribution, and reproduction in any medium, provided the original work is properly cited. 